\title{
Hybrid Learning Design to Minimize Academic Stress of Digital Natives' Generation in Accounting Course
}

\author{
Binti Muchsini ${ }^{1}$, Siswandari $^{2}$ \\ ${ }^{1}$ Teacher Training and Education Sebelas Maret University, Indonesia \\ Email: bintisemnastpuns@gmail.com \\ ${ }^{2}$ Teacher Training and Education Sebelas Maret University, Indonesia \\ Email: semnastpuns@gmail.com
}

(Received: November-2019; Reviewed: December-2019; Accepted: February-2020;

Available online: February 2020; Published: April-2020)

\begin{abstract}
The digital native's generation $(D N G)$ tends to experience relatively high academic stress if the learning design does not pay attention to its characteristics and culture. This study aims to develop a prototype of a hybrid learning model to minimize such stress amongst preservice teachers' accounting. This hybrid learning design combines face to face and online learning using the Design-Based Research (DBR) method with stages of problem analysis when learning, and the development of solutions based on principles and theory. Questionnaires, interviews, FGDs and literature studies were used to collect data that were analyzed using quantitative and qualitative descriptive analysis. The study found that the DNG experiences relatively high academic stress in the accounting context, so it is necessary to develop a prototype of a flipped classroom-type hybrid learning model by considering its learning style and academic culture and based on the sociocultural revolution theory. This hybrid learning design remains to be tested in further research for its feasibility and effectiveness in minimising DNG academic stress.
\end{abstract}

Keywords: Academic Stress; Digital Natives; Hybrid Learning.

\section{INTRODUCTION}

Accounting courses, which require mathematical logical intelligence, are supported by the mastery of theories according to standards. Logical-mathematical intelligence requires mathematical thinking with logical reasoning in terms of solving problems, patterns of cause and effect, formulating hypotheses, numerical patterns and having a rational view of life (Leonard \& Linda, 2018). This is certainly a challenge for lecturers when designing their teaching, especially when the prospective accounting teachers who are on their classes include the digital generation (Prensky, 2001), who have unique learning styles (Barnes, Marateo \& Ferris, 2007), including learning by utilizing technology; are more comfortable with informal learning structures and learning that is not limited by space and time; have a short attention span; provide quick feedback; prefer to learn in teamwork; learn through activities they consider more fun than reading and listening; and use mobile devices in their learning (Sarkar, Ford \& Manzo, 2017). The digital generation is accustomed to fun learning habits, so it is not possible to force them to learn in the oldfashioned way as their brain structures are different from those of previous generations (Prensky, 2001; Kivunja, 2014). The uniqueness of this generation's learning style can be an influence when choosing strategies for presenting lecture material (Prastiti \& Pujiningsih, 2009).

Besides learning styles, culture is also very influential in achieving learning objectives. Understanding cultural values will affect the 
achievement of national education goals that contain such values (Gufron, Budiningsih \& Hidayati, 2017; Gundus et al., 2019). Cultural differences in the classroom can have negative impacts, such as creating a sense of pressure on each individual. Stress is a by-product of achievement due to the ongoing culture (Mrowka, 2014). In the academic environment, this feeling of distress is often referred to as academic stress, in which the demands of the academic environment are greater than students' ability to overcome them, leading to pressure on individuals (Lazarus \& Folkman, 1984) and a subsequent decrease in their academic abilities (Talib \& Zia- ur-Rehman, 2012; Goff, 2011).

Differences in learning styles and DNG culture have become very important when designing learning models. The phenomenon of learning styles and cultural values shows that the digital generation is one that likes to utilize technology in the learning process. DNG technology helps educators to adjust their teaching styles to DNG learning styles, which has a positive impact on learning outcomes (Sarkar et al., 2017). Leidner and Kayworth's research (Liu $\&$ Tang, 2007) shows that different uses of technology depend on the culture that exists in a specific environment. In other words, the use of technology will have a positive impact on learning outcomes if the learning takes into account the learning styles and culture of students.

One appropriate technology-based learning model for the DNG is the hybrid learning model, which combines face-to-face learning and online content (Garrison \& Kanuka, 2004; Klimova \& Kacetl, 2015). Hybrid learning is the latest model that is appropriate for generations who are familiar with technology, and with it students can learn flexibly (Li, Kay \& Markovich, 2018), meaning they are more motivated and have effective communication skills (Ceylan \& Kesici, 2017) as the delivery of material can be made anytime and anywhere, with various learning methods and evaluations (Eshreteh \& Siaj, 2017). Hart et al. (2008) argue that with the hybrid learning model: 1) the learning target will be achieved because there will be more focus and large amounts of material can be delivered over time; 2) learning is more effective due to the variations between online learning and the face-to-face approach; and 3) interactions with students online can be developed. The results of hybrid learning research show that it is more effective in increasing the competence of students (Ceylan \& Kesici, 2017; Kintu, Zhu \& Kagambe, 2017; Dwijonagoro \& Suparno, 2019). Ceylan \& Kesici's (2017) research shows that the contribution of hybrid learning to student competencies is $72 \%$, while Dwijonagoro \& Suparno's (2019) study shows that hybrid learning produces the highest increase in student competency, followed by modeling, e-learning and mind mapping. In other words, hybrid learning plays an important role in increasing DNG competence and is therefore one type of lesson that can be recommended. Consequently, this study aims to develop a hybrid learning design for the DNG in order to minimize their academic stress on accounting courses.

The advantage of this design is the freedom to interact with content according to students' learning styles, students become more aware of their own learning processes. This allows teachers to improve communication and connections with students so that it is expected to minimize academic stress. This design has the potential to overcome situations where students miss college due to illness and for students who are involved in campus activities such as student associations or extracurriculars. Likewise, when a lecturer is absent, the course to proceed as scheduled.

\section{METHOD}

The development of learning design in this study applies the Design-Based Research method (Amiel \& Reeve, 2008), which consists of four phases: phase I, problem analysis during the learning process; phase II, development of solutions based on principles and theories; phase III, the process of applying and improving the design, which begins with internal validation and is then tested on students to gauge its effectiveness; and phase IV, which is reflection. In the development of the prototype of this model, only the stages of problem analysis during the learning process and the development of solutions based on principles and theory were involved. Questionnaires, interviews, FGDs and literature studies were used to collect data. The instrument used in collecting data related to cultural values and academic stress was a questionnaire, in which each variable consisted of 15 valid statement items. Regarding cultural values, the questionnaire refers to Hofstede's scale of cultural dimensions, while for academic stress it refers to Gadzella's Student-Life Stress 
Inventory. 152 prospective accounting teacher candidates participated. Hofstede's cultural dimensions comprise power distance (PD), collectivism-individualism (CI), feminismmasculinity(FM), uncertainty avoidance (UAI) and long-term orientation (LTO) (Hofstede \& Bond, 1984), with a rating scale of 1-10, while the academic stress indicators are based on aspects of reactions to stressors, which consist of four categories, namely physiological, emotional, behavioural and cognitive (Gadzella et al., 2012). The data were analyzed using quantitative and qualitative descriptive analysis.

\section{RESULTS AND DISCUSSION}

\section{Results}

\section{Analysis of the problems found during the learning process}

The results of the data analysis from the questionnaire completed by the 152 Accounting Education students in Surakarta relating to the problems found during the accounting learning process and consequent academic stress are summarised in Table 1

Table 1 Academic Stress Survey Results

\begin{tabular}{lcl}
\hline \multicolumn{1}{c}{ Aspect } & \% Students & \\
\hline Physiological & $75 \%$ & Feel dizzy when given many assignments \\
Emotional & $57 \%$ & Fear of asking lecturers when there is unclear material \\
& $49 \%$ & Fear of expressing opinions/ideas during the learning process \\
& $51 \%$ & Feel nervous when getting a presentation assignment \\
Behavioral & $65 \%$ & Feel bored when learning \\
Cognitive & $73 \%$ & Difficult to understand the language used by the lecturer \\
\hline
\end{tabular}

Based on Table 1, it can be seen that in the physiological category $75 \%$ of students feel dizzy if they are given many assignments by lecturers because most lecturers give assignments without any feedback on assignments already done; $57 \%$ of students are afraid to ask the lecturer when there is an unclear accounting material because they are afraid the question will be inappropriate and they are more comfortable asking a friend; $49 \%$ of students are afraid when expressing opinions/ideas during the learning process because they are afraid that these are wrong; $73 \%$ of students say that the delivery of material by lecturers is made with language that is difficult to understand; $65 \%$ of students state that the delivery of accounting material by lecturers is boring; and $51 \%$ of students feel nervous when they have to make a presentation. This demonstrates that the proportion of DNG who experience academic stress in accounting learning is relatively high.

This high stress in the learning process is caused by several factors, including differences in the habits and ways of thinking between DNG students and lecturers whose age is still classified as a digital immigrant generation. In teaching by lecturers, it is still rare to make use of e-learning. This is proven by the survey results, which show that out of the 152 students, only $2.9 \%$ frequently accessed e-learning websites to do assignments from lecturers. The students tended to use technology for daily activities; for example, $67.6 \%$ often accessed information unrelated to academic purposes, and $47.8 \%$ used it to chat. This shows that the use of technology for academic activities is relatively low compared to activities related to daily life. This phenomenon is a challenge for lecturers to innovate by integrating technology into learning, especially the use of e-learning, because the DNG prefers to learn by doing activities rather than just listening.

Besides learning styles, academic culture must also be considered in the framework of learning design. According to Hofstede \& Bond (1984), culture consists of five dimensions, namely PD, CI, FM, UAI, and LTO. The survey results on DNG academic culture are presented in Table 2.

Based on Table 2, it can be seen that the DNG likes a low PD culture because students are given the freedom to develop creative ideas. A collectivist culture means that students prefer to do assignments in groups rather than individually. Feminism illustrates that there are no differences in the views or thoughts of men and women. Low UAI shows that students are more comfortable in informal learning situations, where they can express ideas and learn from real experiences, while LTO shows that students always make plans by considering everything, 
and are willing to try new and innovative things.

From the results of the interviews with lecturers, students tend to be passive when the learning process takes place, even at the beginning of learning when the lecturer conducts question and answer sessions related to the material to be delivered. In these, almost all the students cannot answer correctly, which shows that they do not first study the material. In addition, the teaching approach used by lecturers in lectures continues to employ the face to face method; although they do sometimes use elearning, it is limited to evaluating the material presented at meetings, so the results are less than optimal. This is one of the reasons why the DNG has problems in learning and appear depressed when following the learning process.

\section{Solution-based development theory}

Based on the identification and analysis of the problems, the following Table 3 presents the development of solutions based on principles and theories. Table 3 Development of solutions.Sociocultural-Revolution From the results of the FGD, based on developing solutions that refer to sociocultural-revolution theory, and taking into account DNG academic learning styles and academic culture, the prototype of the hybrid learning model developed is a flipped classroom (FC) type, utilising SPADA University of Sebelas Maret (UNS) to facilitate online learning. Based on the description above, the initial draft of the hybrid learning design for the DNG is shown in Figure 1.

Table 2 Hofstede Academic Cultural

\begin{tabular}{cc}
\hline Dimension & Result \\
\hline PD & 43 (Low) \\
CI & 47 (Collectivism) \\
FM & 45 (Feminism) \\
UAI & 41 (Low) \\
LTO & 62 (Long) \\
\hline
\end{tabular}

Table 3 Development of Solutions

\begin{tabular}{|c|c|c|c|c|}
\hline Aspect & Problem & $\begin{array}{l}\text { DNG Academic } \\
\text { Culture }\end{array}$ & $\begin{array}{c}\text { DNG Learning } \\
\text { Style }\end{array}$ & $\begin{array}{c}\text { Solutions Based on Sociocultural } \\
\text { Theory }\end{array}$ \\
\hline Physiological & $\begin{array}{l}\text { Students feel } \\
\text { dizzy when they } \\
\text { are given many } \\
\text { individual } \\
\text { assignments. }\end{array}$ & Collectivism & $\begin{array}{l}\text { Love to do } \\
\text { teamwork. }\end{array}$ & $\begin{array}{l}\text { To minimise this problem, the tasks } \\
\text { given should be discussed with } \\
\text { friends. Sharing with friends in } \\
\text { relatation to completing } \\
\text { assignments will minimise stress on } \\
\text { individual students. }\end{array}$ \\
\hline \multirow[t]{2}{*}{ Emotional } & $\begin{array}{l}\text { Students feel } \\
\text { afraid to ask } \\
\text { questions and } \\
\text { express } \\
\text { opinions/ideas } \\
\text { during the } \\
\text { learning process. }\end{array}$ & $\begin{array}{l}\text { Low self- } \\
\text { confidence }\end{array}$ & $\begin{array}{l}\text { Comfortable } \\
\text { with informal } \\
\text { learning } \\
\text { structures. }\end{array}$ & $\begin{array}{l}\text { The learning process is directed at } \\
\text { the process of constructing new } \\
\text { knowledge or meaning together. }\end{array}$ \\
\hline & $\begin{array}{l}\text { Students feel } \\
\text { nervous when } \\
\text { presenting. }\end{array}$ & Feminism & $\begin{array}{l}\text { Learning is not } \\
\text { limited by time } \\
\text { and space. }\end{array}$ & $\begin{array}{l}\text { Use strategies to develop their } \\
\text { confidence }\end{array}$ \\
\hline Behavioural & $\begin{array}{l}\text { Feel bored when } \\
\text { learning. }\end{array}$ & Low UAI & $\begin{array}{l}\text { Love to use } \\
\text { technology. }\end{array}$ & $\begin{array}{l}\text { Facilitate an online discussion room } \\
\text { to accommodate questions and ideas } \\
\text { that cannot be conveyed orally. }\end{array}$ \\
\hline Cognitive & $\begin{array}{l}\text { Difficult to } \\
\text { understand the } \\
\text { language used } \\
\text { by the lecturer. }\end{array}$ & LTO & $\begin{array}{l}\text { Learning } \\
\text { through } \\
\text { activities }\end{array}$ & $\begin{array}{l}\text { Provide an opportunity to integrate } \\
\text { the declarative knowledge learnt } \\
\text { with procedural knowledge in order } \\
\text { to solve problems. }\end{array}$ \\
\hline
\end{tabular}




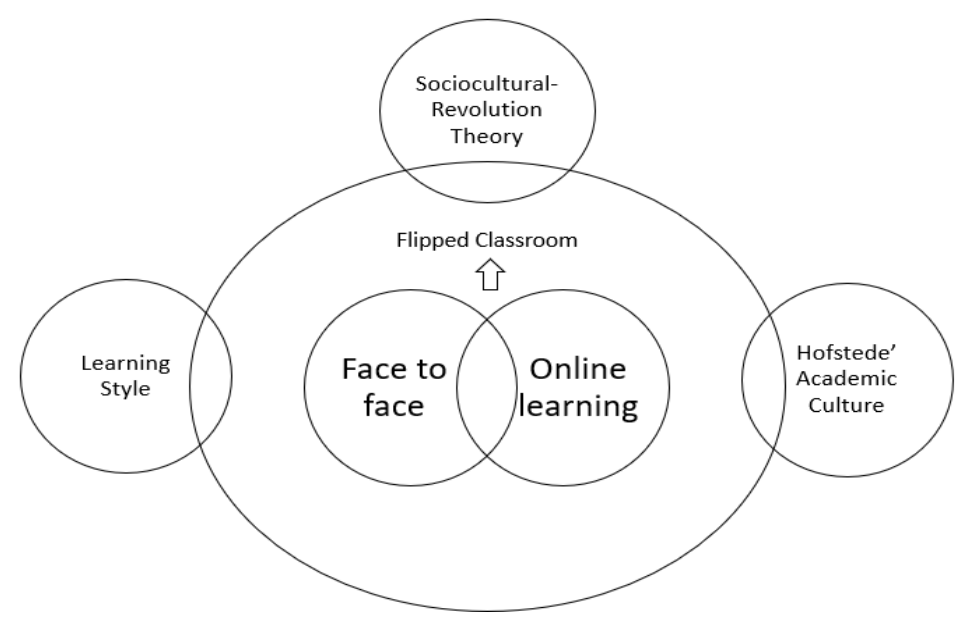

Fig 1 Prototype FC - Type Hybrid Learning Model

\section{Discussion}

The DNG adopts a very unique and fun learning style (Barnes, et al. 2007; Prensky, 2001), so students will feel pressured if forced to learn in the old way because they have a different brain structure from previous generations (Prensky, 2001; Kivunja, 2014). The uniqueness of their learning style is especially related to their fondness for the use of technology; informal learning structures; learning not limited by space and time; fast feedback; learning by teamwork; learning through activities; and utilizing mobile devices (Sarkar, et al. 2017), so these aspects must be considered when choosing methods and content when presenting learning material (Prensky, 2001; Prastiti \& Pujiningsih, 2009).

Aside from learning styles, stress can be caused by cultural differences. Stress is a byproduct of achievement due to the ongoing culture (Mrowka, 2014). High PD learning uses the Teacher Centered Learning (TCL) approach, while low PD uses the Student Centered Learning (SCL) approach. In the TCL approach, students will be afraid to themselves, ask questions and build their own knowledge (Mpho, 2018), and teachers are more authoritarian, so students tend to be passive, calm, silent and polite in class because of fear, not because of respect (Cristillo, 2010; Saber, 2018). Conversely, SCL teachers are more democratic and respect student opinions (Lak, Soleimani, \& Parvaneh, 2017), which will create a conducive atmosphere, so a low PD culture must be considered when designing learning. This is in line with the theory of sociocultural revolution, in which the learning process is directed at the process of constructing new knowledge or meaning together (Budiningsih,
2003). A collectivist culture is more socially oriented; that is, it prioritises group interests (Hofstede \& Bond, 1984; Popa, Guillet, Mullet, 2014). Students tend to be depressed when they have to do assignments without the help of friends. They feel happy and comfortable discussing with friends when working on assignments, rather than completing them themselves (Kormi-Nouri et al., 2015). Based on the theory of socio-cultural revolution, an increase in mental function comes from social life or groups (Budiningsih, 2003); therefore, learning design should use a collaborative approach. Feminist culture is based on the opinion that gender does not differentiate in terms of views or thoughts (Hofstede \& Bond, 1984). Accounting Education students in Surakarta are almost $90 \%$ female; male students often discuss with them when completing assignments because they are considered to have good views and thoughts on understanding accounting material. This will foster self-confidence when the female students submit ideas or give opinions when presenting. Low UAI views something different with curiosity; students prefer open learning situations where there is room to express their ideas and it is easier to learn from real experiences (Joy \& Kolb, 2009). Therefore, it is important to facilitate an online discussion room to accommodate questions and ideas that cannot be conveyed orally. In LTO culture, individuals are future-oriented, so planning is always made carefully, people are willing to take risks, and they are persistent (Joy \& Kolb, 2009), more innovative and tolerant of change (House et al., 2004). Socio-cultural theory provides an opportunity to integrate declarative knowledge 
learnt with procedural knowledge in order to solve problems (Budiningsih, 2003). Understanding DNG academic culture in the class will give ideas on how to design appropriate learning.

One learning model that utilizes technology and fits the DNG learning style and academic culture is the hybrid learning model. This combines face-to-face learning (online-toface) and online learning (Garrison \& Kanuka, 2004; Klimova \& Kacetl, 2015), which is appropriate for generations who are familiar with technology; allows more flexible learning $(\mathrm{Li}$, Kay, \& Markovich, 2018); motivates and develops communication skills (Ceylan \& Kesici, 2017); and material can be delivered anytime and anywhere (Eshreteh \& Siaj, 2017). Hybrid learning is more effective in increasing the competency of students (Ceylan \& Kesici, 2017; Kintu, Zhu, \& Kagambe, 2017; Dwijonagoro \& Suparno, 2019). In other words, hybrid learning plays an important role in increasing DNG competence and is therefore one type of lesson that can be recommended. Consequently, this study has aimed to find a hybrid learning design for the DNG in order to minimise students' academic stress on accounting courses.

Based on the results of development solutions that refer to the socio-cultural revolution theory, considering DNG academic learning styles and culture, the hybrid learning design proposed is the flipped classroom (FC) type, utilising SPADA UNS to facilitate online learning. The FC is defined as an inverted class; that is, activities normally conducted in class are now conducted at home, and activities conducted as homework are now completed in class (Bergmann \& Sams, 2012; Tucker, 2012; Lage, Platt \& Treglia, 2000). In the FC, students conduct activities in the classroom including problem-solving, discussion of important concepts, and active involvement in collaborative learning (Tucker, 2012). The FC increases interaction between students, and between students and educators (Ash, 2012); performance is improved (Amresh, Carberry \& Femiani, 2013; Schmidt, 2016); and problem-solving abilities also improve (Mazur, 2009).

\section{CONCLUSIONS AND SUGGESTION}

Following the uniqueness of DNG Hofstede academic learning styles and culture based on socio-cultural theory, the prototype of the hybrid learning model is an FC type using
SPADA UNS for online learning. In the FC, student activities include problem solving, discussion of important concepts, and active involvement in collaborative learning, which increase interaction between students and between students and educators, and improve performance and problem solving abilities.

Suggestions from researchers, so that Accounting Education Department in FKIP UNS can minimize academic stress of students, in order to improve performance and problem solving abilities of students.

\section{REFERENCES}

Amiel, T., \& Reeves, T. C. (2008). Design-based Research and Educational Technology: Rethinking Technology and The Research Agenda. Educational Technology \& Society, 11(4), 29-40.

Amresh, A., Carberry, A. R., \& Femiani, J. (2013). Evaluating the Effectiveness of Flipped Classrooms for Teaching CS1. In Frontiers in Education Conference, 2013 (pp. 733-735)

Ash, K. (2012). Educators View Flipped' Model With a More Critical Eye: Benefits and drawbacks seen in replacing lectures with on-demand video. Education Week, p56-57

Barnes, K., Marateo, R. C., \& Ferris, S. P. (2007). Teaching and Learning with the Net Generation Innovate: Journal of Online Education 3(4): 1-8

Bergmann, J., \& Sams, A. (2012). Flip your Classroom: Reach Every Student in Eevery Class Every Day. International society for technology in education, pp. 120-190

Budiningsih, C.A. (2003). Perkembangan Teori Belajar dan Pembelajaran Menuju Revolusi-Sosiokultural. Dinamika Pendidikan, 10(1)

Ceylan, V. K., \& Kesici, A. E. (2017). Effect of Blended Learning to Academic Achievement. Journal of Human Sciences, 14(1), 308-320. doi:10.14687/jhs.v14i1.4141 
Cristillo, L. (2010). Struggling for the center: Teacher-Centered vs Learner-Centered Practices in Palestinian Higher Education. Higher Education and the Middle East, 2, 37-40

Dwijonagoro, S \& Suparno. (2019). Pranatacara Learning: Modeling, Mind Mapping, ELearning, or Hybrid Learning?. Cakrawala Pendidikan, 38(1). doi: $10.21831 /$ cp.v38i1.23034

Eshreteh, K. M. \& Siaj, A. H. (2017). Attitudes of English-Major Students and Teachers towards Using Blended Learning in the English Department at Hebron University. International Journal Research in English Education, 2(4), 5165. doi:10.29252/ijree.2.4.51.

Gadzella, B.M., Baloglu, M., Masten, W. G., \& Wang, Q. (2012). Evaluation of the Student Life-stress Inventory-Revised. Journal of Instructional Psychology, $39(2)$

Gufron A., Budiningsih C A., \& Hidayati. 2017. Pengembangan Pembelajaran Berbasis Nilai-Nilai Budaya Yogyakarta Di Sekolah Dasar. Cakrawala Pendidikan. TH. XXXVI. No. 2. 309-319. doi: 10.21831/cp.v36i2.12449

Gundus, M., Aktepe, V., Sulak, S. E., Baspinar, Z., \& Buyukkarci, E. (2019).Cultural Values Defining Turkish Nation: From the Perspectives of History Teachers. International Journal of Instruction, 12(22), 193-208, doi: 10.29333/iji.2019.12213a

Hofstede, G., and Bond, M. H. (1984). Hofstede's Culture Dimensions: An Independent Validation Using Rokeach's Value Survey. Journal of Cross-Cultural Psychology 15(4): 417-433

House, R.J., Hanges, P.J., Javidan, M., Dorfman, P. W., \& Gupta,V. 2004. Culture, Leadership and Organizations: The GLOBE Study of 62 Societies. Sage Publications Inc.

Joy, S., \& Kolb, D A. 2009. Are There Cultural Differences in Learning Style?.
International Journal of Intercultural Relations. $\quad 33(2009) .69-85$. doi:10.1016/j.ijintrel.2008.11.002

Kintu, M. J., Zhu, C. H., \& Kagambe, E. (2017). Blanded Learning Effectiveness: The Relationship Between Student Characteristic, Design Features, and Outcome. International Journal of Educational Technology in Higher Education, 14(7), 1-20. doi:10.1186/s41239017-0043-4.

Kivunja, C. (2014). Theoretical Perspectives of How Digital Natives Learn. International Journal of Higher Education 3(1). 1927-6044.

Klimova, B. F. \& Kacetla, J. (2015). Hybrid Learning and its Current Role in the Teaching of Foreign Languages. Procedia-Social and Behavioral Sciences, 182(2015), 477-481. doi:10.1016/j.sbspro.2015.04.830.

Kormi-Nouri, R., MacDonald, S., Farahani, MN., Trost, K., \& Sokri, O. (2015). Academic Stress as A Health Measure and Its Relationship to Patterns of Emotion in Collectivist and Individualist Cultures: Similarities and Differences. International Journal of Higher Education 4(2), 92-104. doi:10.5430/ijhe.v4n2p92

Lage, M.J., Platt G.J., \& Treglia, M. (2000). Inverting the Classroom: A Gateway to Ccreating an Inclusive Learning Environment. The Journal of Economic Education, 31, 30-43

Lak, M., Soleimani, H., \& Parvaneh, F. 2017. The Effect of Teacher-Centeredness Method vs. Learner-Centeredness Method on Reading Comprehension among Iranian EFL Learners. Journal of Advances in English Language Teaching. 5(1). 1-10.

Lazarus, R S., \& Folkman, S. 1984. Stress, Appraisal, and Coping. New York: Springer Publishing Company

Leonard, \& Linda, N N. (2018). Pengaruh Kecerdasan Logis-Matematis Dan Kecerdasan Musikal Terhadap Higher 
Order Thinking Skills (HOTS). KALAMATIKA Jurnal Pendidikan Matematika, 3(2). 193-208

Li, J., Kay, R., \& Markovich, L. (2018). Student Attitudes toward Blended Learning in Adult Literacy and Basic Skills College Programs. Canadian Journal of Learning and Technology, 44(2), 1-36. doi:10.21432/cjlt27573.

Mazur, E. (2009). Farewell, Lecture? Science 323: $50-51$

Mpho, O. 2018. Teacher centered dominated approaches: Their implications for today's inclusive classrooms. International Journal of Psychology and Counselling. 10(2), 11-21.

Mrowka, K A K. 2014. Academic Stress in an Achievement Driven Era: Time and School Culture. 789 East Eisenhower Parkway: ProQuest LCC. https://www.hanoverhigh.org/uploaded/ Hanover_High_School/Library/Staff_Re search/Academic_Stress_in_an_Achieve m.pdf

Popa, B., Guillet, L., \& Mullet, E., (2014). Cultural Differences in the Appraisal of Stress. Psicologica, 35, 745-760
Prastiwi, S. D., \& Pujiningsih, S., (2009). Pengaruh Faktor Preferensi Gaya Belajar terhadap Prestasi Belajar Mahasiswa Akuntansi. Jurnal Ekonomi Bisnis, 14(3), 224-231.

Prensky, M. (2001). Digital native - digital immigrant. On the Horizon. 9(5).

Saber, M D. 2018. The Impact of the Teachercentred Pedagogy on Today's learners in Algerian Schools. Annales des lettres et des langues. 5(10). 38-51

Sarkar, N., Ford, W., \& Manzo, C. (2017). Engaging Digital Natives Through Social Learning. Systemics. Cybernetics and Informatics. 15(2).Schmidt, S M P. (2016). The Flipped Classroom: A Twist On Teaching. Contemporary Issues in Education Research. 9(1).

Schmidt, S M P. (2016). The Flipped Classroom: A Twist On Teaching. Contemporary Issues in Education Research. 9(1). 